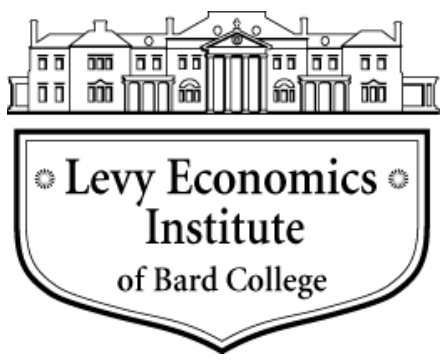

Working Paper No. 973

\title{
The Trade-off between Inflation and Unemployment in an MMT World: An Open Economy Perspective
}

\author{
by \\ Emilio Carnevali \\ Northumbria University \\ and \\ Matteo Deleidi \\ University College London
}

October 2020

The Levy Economics Institute Working Paper Collection presents research in progress by Levy Institute scholars and conference participants. The purpose of the series is to disseminate ideas to and elicit comments from academics and professionals.

Levy Economics Institute of Bard College, founded in 1986, is a nonprofit, nonpartisan, independently funded research organization devoted to public service. Through scholarship and economic research it generates viable, effective public policy responses to important economic problems that profoundly affect the quality of life in the United States and abroad.

\author{
Levy Economics Institute \\ P.O. Box 5000 \\ Annandale-on-Hudson, NY 12504-5000 \\ http://www.levyinstitute.org
}

Copyright (C) Levy Economics Institute 2020 All rights reserved

ISSN 1547-366X 


\begin{abstract}
This paper is focused on Modern Monetary Theory's (MMT) treatment of inflation from an open economy perspective. It analyzes how the inflation process is explained within the MMT framework and provides empirical evidence in support of this vision. However, it also makes use of a stock-flow consistent (open economy) model to underline some limits of the theory when it is applied in the context of a non-US (relatively) open economy with a flexible exchange rate regime. The model challenges the contention made by MMTers that measures such as the job guarantee program can achieve full employment without facing an inflation-unemployment trade-off.
\end{abstract}

KEYWORDS: Central Banking; Post-Keynesian; Open Economy Model; Modern Money Theory

JEL CLASSIFICATIONS: E51; E120; F410 


\section{INTRODUCTION}

This paper ${ }^{1}$ is focused on the Modern Monetary Theory's (MMT) treatment of inflation from an open economy perspective.

After a summary of the main theoretical elements of MMT and of their origins in the history of economic thought (section 2), the paper reconstructs its theory of inflation and the proposal of a job guarantee (JG) program as a measure able to achieve full employment without triggering any wage-price spiral, and more generally without generating any inflation process (section 3). MMT relies on an active role played by the central bank for its policy prescriptions to be implemented and this approach has often been stigmatized by its critics as a recipe for hyperinflation (section 4). In section 5, we show that criticism based on the correlation between the (increased) monetary base and inflation cannot be supported by empirical evidence.

However, the impact of "full employment" fiscal policies on the current account position of a country seems to be one of the major critical points of the prescriptions elaborated within this theoretical framework. Even countries that are relatively high in the hierarchical international monetary and financial system cannot overlook problems related to the potential depreciation of their currency and its inflationary consequences. In section 5 we test the JG program in an "ideal MMT world" via a stock-flow consistent (SFC) open economy model, building on the benchmark created by British economist Wynne Godley and Marc Lavoie (2007). MMT endorses the sectorial balance approach to national accounting pioneered by Godley and therefore this kind of macro models seems particularly suitable for the purpose.

The results of the simulations demonstrate that an MMT-style fiscal policy can be very effective in boosting employment even in a relatively open economy with flexible exchange rates. Yet, the contention that the JG program can achieve full employment without generating inflation does not find validation. MMT claims that the traditional trade-off between inflation and

\footnotetext{
${ }^{1}$ We would like to thank Gennaro Zezza for his very useful comments of the first draft of this paper. Of course, all errors remain ours.
} 
unemployment can be averted, whereas our $\mathrm{MTO}^{2}$ model tells a different story. The comeback of the Phillips curve can be one of the paradoxes of the implementation of the MMT policy prescriptions in a world where the Phillips curve seems to have disappeared.

\section{WHAT IS MMT}

In his Nobel Memorial Lecture (1981), the American economist James Tobin declared that "macro-economic models of one brand or another are very influential. [...] They shape the thinking of policy-makers and their advisers about 'the way the world works.' They color the views of journalists, managers, teachers, housewives, politicians, and voters. Almost everyone thinks about the economy, tries to understand it, and has opinions on how to improve its performance. Anyone who does so uses a model, even if it is vague and informal."

Although it is hard to question the influence of economic theories in politics and in the public debate, this influence is usually exerted in a very indirect way. Nonspecialist readers rarely engage in the same debates that are taking place at an academic level. And often academic scholars try to keep their interventions directed to their peers and the ones directed to the wider public separated.

The outbreak of the 2008 financial crisis has somehow loosened these barriers. The success of books like Thomas Piketty's Capital in the Twenty-First Century (2014) is an example of the general public's growing interest in economic theory and related topics. The debate on MMT is another case in point. In the United States, the circulation of ideas propounded by MMT authors has been further strengthened by the endorsement of popular political figures, like the Democrat Congresswoman Alexandria Ocasio-Cortez. The economist Stephanie Kelton, one of the main representatives of this group of scholars, has been chief economic advisor to US presidential candidate Bernie Sanders.

\footnotetext{
${ }^{2}$ MTO is our short-hand version of "MMT test in an open economy" model. Its code can be provided upon request
} 
All this attention to MMT has come with both positive and negative consequences. On the one hand, it has helped the public to better understand that economics is not a purely "technical" discipline and economists can disagree on the way the world works and what are the best policies to implement. The democratic "ecosystem" can surely benefit from a more pluralistic approach to economic debates. On the other hand, the discussion has sometimes been distorted by arguments that are the results of an oversimplification of what both MMT theorists and their critics think and write. It has not helped the fact that the "MMT world" comprises not only "a core group of scholarly driven" researchers, but also "a more activist-driven group [...] These activists are not, in most cases, scholarly trained and often have limited knowledge of economics" (Rochon 2019, 157).

The publication of Macroeconomics, the first macroeconomics "handbook" from an MMT perspective by William Mitchell, L. Randall Wray, and Martin Watts (2019), has been very important in providing an "official reference" of the core of the theory previously scattered in numerous publications and academic papers. The book will be also an important reference for this paper.

A special issue of the Real-World Economics Review (89) has recently offered a good presentation of the state of the debate on MMT, featuring contributions from supporters, adversaries, and several other economists that cannot be easily classified in as holding one view or another.

A complete literature review on MMT goes beyond the scope of this paper. In the rest of this section we will summarize some of the key points that characterize the theory, with a particular focus on the elements relevant for the treatment of inflation-related issues. Many of these ideas have been part of the Post-Keynesian tradition for long time. In this context we are interested in discussing the ideas linked to MMT rather than their level of originality.

"The most important conclusion reached by MMT is that the issuer of a currency faces no financial constraints. Put simply, a country that issues its own currency can never run out and can never become insolvent in its own currency. It can make all payments as they come due. For this 
reason, it makes no sense to compare a sovereign government's finances with those of a household or a firm" (Mitchell, Wray, and Watts 2019, 13).

The statement is grounded on a specific theory of money and its origin (chartalism or neochartalism in its latest developments), which ultimately derives from the work of Mitchell Innes (1913, 1914), Georg Friedrich Knapp (1924), and John Maynard Keynes ([1930] 2011).

The reference to the "sovereign government" in the quotation above is crucial. MMT authors assert their theory only applies to governments with a sovereign currency. The definition of the latter is one of the most debated and controversial aspects of the MMT.

Money is a creation of the State and taxes "drive money": a certain currency is accepted as a means of payment - even when is not "backed up" by precious metals, like in modern fiat currency systems - because citizens know themselves, or other fellow citizens, can pay taxes with it. ${ }^{3}$ Two of the most important requirements ${ }^{4}$ for qualifying a currency as sovereign are: 1 ) the liabilities of the government must all be denominated in that currency (e.g., government bonds cannot be denominated in a foreign currency, such as the US dollar if the government in question is not the United States); and 2) the government must adopt a floating exchange rate regime (e.g., its central bank should not promise to redeem the local currency for a fixed quantity of foreign currency). Although these and other requirements are often used for "binary" classification of international currencies (e.g., sovereign vs nonsovereign currencies), MMT authors like Eric Tymoigne and Wray (2013) and Nathan Tankus (2018) have underlined that monetary sovereignty is a "spectrum" that features different degrees and level of sovereignty. In any case, MMTers have strongly denied that their theory - and the policy prescriptions that go with it - only apply to the country that issues the currency used as international reserve (i.e., the United States). Countries that can be considered "sovereign currency nations" from the point of view of the MMT "account for the vast majority of global GDP—perhaps well above 80 percent" (Wray 2019, 7).

\footnotetext{
${ }^{3}$ For a critical appraisal of the argument that "taxes drive money" and its relationship with Keynes's theory of money, see Kregel (2019).

${ }^{4}$ For a more detailed list, see Wray $(2019,5)$.
} 


\section{INFLATION AS EXPLAINED BY MMT}

MMT's theory of inflation explicitly takes inspiration from the works of Michał Kalecki (1943) and Keynes ([1936] 2017, 1940). As Keynes ([1936] 2017, 262) put it in chapter 21 of the General Theory: "When a further increase in the quantity of effective demand produces no further increase in output and entirely spends itself on an increase in the cost-unit fully proportionate to the increase in effective demand, we have reached a condition which might be appropriately designated as one of true inflation." MMT would call "demand pull" inflation what Keynes called "true inflation." It occurs when the system reaches the point of full utilization of its productive capacity, both in terms of capital utilization and in terms of availability of workers. At this point, the government should curb inflation forces cooling down the effective demand. This is another fundamental task of taxes. We have already seen that from an MMT perspective taxes "drive the money," in other words they make the money of account chosen by the state accepted for payments. "The second reason to have taxes (once a currency is established and widely adopted) is to reduce aggregate demand" (Mitchell, Wray, and Watts 2019, 323) to keep inflation in control. In this way "taxes create real resources space in which the government can spend to fulfil its socio-economic mandate. Taxes reduce the non-government sector's purchasing power and hence its ability to command real resources, leaving real resources for the government to command its spending” (Mitchell, Wray, and Watts 2019, 323).

That is not a trivial problem at all. In his recent critical assessment of MMT, Jan Kregel (2019, 86). has pointed out that the real challenge in the main political issues of our time - such as the environmental risks and the Green New Deal that has been advocated to combat them-rests on "the availability of appropriate resources, and if there are none, the policy process of shifting resources to these uses." MMTers tend to respond to this kind of argument by stressing that in contemporary societies demand pull inflation should be considered a limit case, given the fact that "fortunately — or unfortunately, depending on one's view_modern economies usually operate with sufficient slack" (Wray 2019, 7). 
However, prices can rise and an inflation phenomenon can materialize even before the point of full capacity utilization is reached. This is not only due to the fact that in the productive system there are several bottlenecks and different sectors hit their maximum production at different moments in time, so that an "inflation gap" can appear in certain industries even when there are still idle resources in the system.

MMTers reject the law of diminishing returns, therefore the increase in costs and prices that can follow an increase in production before the point of full capacity utilization should not be explained through a decrease in productivity. Instead, MMTers endorse Kalecki's vision of inflation as the result of the distributional struggle over the respective shares of income between different sectors, or classes, of society. A higher level of employment, or a lower level of unemployment, can encourage workers to claim higher nominal wages, triggering a wage-price spiral.

Given the fact that for MMTers the achievement of full employment should be among the main duties of a government, instruments are required to manage in an orderly way the fundamental trade-off between inflation and employment that has been at the center of macroeconomic debate since Phillips's famous paper, ${ }^{5}$ published in 1958.

A first tool is given by income policy: the Scandinavian model based on the distinction between a competitive sector (where wages can only grow in line with productivity gains and foreign inflation) and sheltered sector (where wages should be aligned with the ones of the competitive sectors, is described in the MMT handbook as a good example of this approach's utilization (see Mitchell, Wray, and Watts 2019, 17).

\footnotetext{
${ }^{5}$ The relationship between unemployment and inflation is usually referred to as the Phillips curve in the economic literature, after the work of the New Zealand economist Alban William Phillips. Actually, the relationship studied by Phillips in his 1958 seminal paper was between unemployment and change in the nominal wage rate. What has become known as the Phillips curve is the price-level modified curve built by Paul Samuelson and Robert Solow (1960).
} 
Yet the main idea put forward by MMTers is the use of the so-called buffer employment ratio (BER). A job guarantee (JG) program should ensure that workers that cannot find a job and would swell the ranks of the unemployed could receive a job offer from the government at a national minimum wage. The BER is defined as the ratio between people employed by the JG program over the total employment in the economy. Evidently, the BER would be higher in a time of recession and lower in a time of expansion, as people tend to move to non-JG positionswhere the wages are higher-when there is the possibility to do so. However, the BER could also be "actively" used to manage inflation pressures in the same way the unemployment buffer stock has been traditionally used under inflation-targeting monetary policy regimes. If the economy is getting closer to full capacity utilization, the government could increase taxes (or cut expenditure) in order to diminish aggregate demand, raise the BER, and cool inflation.

Traditional (Keynesian) fiscal policies could still play a crucial role in case of severe recessions to avoid deep slumps, or more generally when the system is far from its full potential. Yet when the economy is in relatively good health only the JG, according to MMTers, can reach full employment without triggering an inflation spiral. Indeed, Keynesian policies focused on public expenditure "attempted to maintain full capacity utilization by 'hiring off the top' (that is, making purchases at market prices and competing for resources with all other sources of spending in the economy). In practice, these policies often focused spending on the most advanced sectors employing higher-skilled (usually unionized) workers in the defense sector, for example" (Mitchell, Wray, and Watts 2019, 304).

By contrast, the JG program buys labor off the bottom, and doing so does not contribute to the reinforcement of the distributional conflict and the related inflation tendency. MMT theorists think of the JG program as part of a broader strategy carried out by the government to honor its social duties. This strategy harkens back to Abba Lerner's $(1943,39)$ concept of functional finance: "The first financial responsibility of the government (since nobody else can undertake that responsibility) is to keep the total rate of spending in the country on goods and services neither greater nor less than the rate which at the current prices would buy all the goods that is possible to produce." 
Through the combination of traditional Keynesian fiscal policies and a JG program, MMT claims to have overcome the once unavoidable trade-off between inflation and unemployment. The Phillips curve in an MMT world still exists, but it can be "flattened" on the left-hand side at virtually any point, depending on the level of the BER. ${ }^{6}$

\section{HOW WILL YOU PAY FOR IT? MMT AND DEFICIT SPENDING}

If the government needs to keep the total rate of spending in the country at a level that ensures full employment, one could raise the question: How should this spending be funded? The issue has been widely debated. Even among MMT theorists, the topic has not been tackled unambiguously. The tendency of many MMTers to consolidate the treasury and the central bank in a unique identity has created some confusion between the "normative level" and the "descriptive level" of the discussion (how the things should work and how they actually work). The positions have also evolved through time, as Lavoie $(2013,14)$ pointed out in his analysis of the "consolidation problem": "Neo-Chartalists [...] have put some water in their wine, as the French say, admitting now that things are not as clear-cut as they originally seemed."

When MMTers say the government does not need to borrow from the private sector before spending the money, the stance could be interpreted in two ways: 1) that the government does not borrow, and it initially uses the reserves credited by the central bank to its account at the same institution; and 2) that the government does borrow, but it would not be necessary to do that if the central bank credited the money to its account. The second interpretation is the one clearly suggested by Wray $(2019,19)$ when he writes that "since the Fed is not supposed to allow 'overdraft,' Treasury will need to sell bonds over the course of the year even if it ends the year with total tax revenues greater than spending."

\footnotetext{
${ }^{6}$ MMT theorists have also defined the concept of the non-accelerating inflation buffer employment ratio (NAIBER). However, we think that this concept is highly problematic, given its evident link with the non-accelerating inflation rate of unemployment (NAIRU). The NAIRU model is based on assumptions that seem incompatible with the MMT "model." At any rate, since MMTers have not devoted any effort to estimating country-specific NAIBERs and do not promote any policy of targeting a particular level of NAIBER, we can consider this concept as inessential to the overall picture.
} 
There is a reason why MMTers have dwelled on the ambiguity for so long: it does not make so much difference to distinguish how the process started so long as it leads to identical outcomes ex post. All deficit spending means a certain level of currency emission. ${ }^{7}$ The proportion between the currency emission (creation of monetary base) and government bonds bought by the private sector is "determined by decisions made by households, firms, financial institutions" and that is why there could be no "ex ante decision of treasury to either borrow or print money" (Mitchell, Wray, and Watts 2019, 335). Even if the central bank funded deficit spending by direct purchases of government bonds, the excess of liquidity injected in the system via government purchases of goods and service should be drained from the banking sector as long as the central bank wants to keep control of the overnight interest rate. ${ }^{8}$ Draining excess monetary base from the system means selling government securities to it. And, again, only the decisions made by households, firms, financial institutions" can set the level of what is in "excess.

All this has huge implications on the theory of inflation. When critics of MMT say that its policy prescriptions are a recipe for (hyper)inflation, they usually refer to this process of currency emission that necessarily follows government deficit spending. The link between the monetary base and money supply assumed by the money multiplier theory and the link between money supply and level of prices assumed by the quantitative theory of money are often the background of the most alarmist outcries on the danger of the MMT policies. An example of this approachalthough with a much more moderate and dialogic tone-is the recent "Skeptic's Guide to Modern Monetary Theory," by Gregory Mankiw (2020). His contribution is explicitly based on the assumptions of "the mainstream view, explained most simply by the quantity theory of money, that a high rate of money creation is inflationary" (Mankiw 2020,3). Mankiw adds that "mainstream macroeconomists also go beyond the most simplistic quantity theoretic reasoning,"

\footnotetext{
${ }^{7}$ From a purely theoretical point of view we could have deficit spending without creation of monetary base if the private banking sector does not intervene in the purchase of government bonds and the latter are entirely bought by the public with their bank deposits. However, this is a purely theoretical case, indeed, with no correspondence in reality.

${ }^{8}$ This is what happens in "normal times." The central bank can also decide to push the overnight rate on the "floor of the corridor" (meaning at the level of the deposit rate); in this case the excess liquidity is not drained from the system. However, this outcome can be produced even when there are no purchases of government bonds in the primary market by the central bank, as the experience of quantitative easing in the European Union has clearly demonstrated.
} 
but he also acknowledges that "these ideas refine the quantity theory of money rather than refute it" (Mankiw 2019, 4).

In the next section, we will provide some empirical evidence to test the hypothesis that monetary base creation could represent a risk factor for inflationary or hyperinflation spirals.

\section{MONETARY BASE AND INFLATION: EVIDENCE FROM RECENT US DATA}

In order to assess the relationship between the monetary base and prices, we make use of structural vector autoregression (SVAR) modeling on US monthly data provided by the Federal Reserve Bank of St. Louis (FRED). We use the industrial production index (Y), the federal fund rate $(\mathrm{FF})$, the level of prices $(\mathrm{P})$, and the monetary base (MB). All time series are seasonally adjusted. They start from January 1959 and end in November 2019. All the variables-except the $\mathrm{FF}$ - are transformed in logarithm form and are reported in appendix A.

The first step consists of the estimation of a reduced-form $\operatorname{VAR}(\mathrm{p})$, shown in equation (I):

$$
y_{t}=c+\sum_{i=1}^{p} A_{i} y_{t-p}+u_{t}
$$

where $y_{t}$ is the $k x 1$ vector of considered variables, $\mathrm{c}$ is the constant term, $A_{i}$ is the $k x k$ matrix of reduced-form coefficients, and $\mathrm{u}_{\mathrm{t}}$ is a $k \times 1$ vector composed by the error terms. The lag $\mathrm{P}$ of the VAR is calculated through the Akaike information criterion (AIC). As shown in table A1 (appendix A), the optimal lag is 10. We have also checked the stationarity of the VAR(p) by assessing whether the inverse roots of the characteristic polynomial lie inside the unit circle (table A2). 
To obtain an SVAR, an identification strategy has to be imposed to the reduced-form VAR(p) (equation I). More precisely, a SVAR(p) can be represented by the following equation (II):

$$
B_{0} y_{t}=c+\sum_{i=1}^{p} B_{i} y_{t-p}+w_{t}
$$

where $B_{0}$ represents the matrix of contemporaneous relationships between the k variables in $y_{t}$, $\mathrm{B}_{\mathrm{i}}$ is the $k x k$ matrix of autoregressive slope coefficients, and $w_{t}$ is the vector of structural shocks (Kilian and Lütkepohl 2017). ${ }^{9}$ Once zero short-run restrictions are imposed in $\mathrm{B}_{0}$ and the SVAR is estimated, impulse response functions (IRFs) are calculated. Standard errors are estimated through the Monte Carlo methods (1,000 repetitions) and IRFs are reported with twostandard error bound, namely a 95 percent confidence interval.

The identification strategy is based on Cholesky factorization and variables have been ordered as follows: $\left[F F_{t} ; P_{t} ; Y_{t} ; M B_{t}\right]$. In line with the Post-Keynesian endogenous money theory (Lavoie 1996; Rochon 1999, 2001; Deleidi 2020) and with the identification strategy used in Deleidi (2019), we assume an exogenous interest rate controlled by the Fed and the endogenous monetary base $(M B)$. As $M B$ is ordered as the last variable, we are assuming that changes in $F F$, $P$, and $Y$ can affect the monetary base within the monthly observation. ${ }^{10}$ The model is estimated for all the available periods (1959M01-2019M11) and for the precrisis "interval" (1959M012007M12).

Findings are reported in figure 1 and figure 2 and, for the sake of simplicity, we discuss the effect of an increase in $\mathrm{MB}$ on the level of $\mathrm{P}$. As shown in figure 1, an exogenous increase in $M B$ (response of $\mathrm{MB}$ to $\mathrm{MB}$ ) does not produce any positive effect on $\mathrm{P}$ (response of $\mathrm{P}$ to $\mathrm{MB}$ ). The same picture is confirmed in figure 2, where the 1959M01-2007M12 interval is considered. Again, an increase in MB does not trigger any positive pressure on $\mathrm{P}$. Therefore, our findings confirm the theoretical intuition of MMTers.

\footnotetext{
${ }^{9}$ The covariance matrix of structural errors is normalised: $\mathbb{E}\left(\mathrm{w}_{\mathrm{t}} \mathrm{w}_{\mathrm{t}}^{\prime}\right)=\sum_{\mathrm{w}}=\mathrm{I}_{\mathrm{K}}$ (Lütkepohl 2005).

${ }^{10}$ As a robustness check, we assume a second identification strategy where $F F$ is ordered last, namely it is considered as an endogenous variable. Findings can be provided upon request and are in line with the ones obtained with our main identification strategy.
} 
Figure 1: Impulse Response Functions (IRFs), 1959M01-2019M11

Response of FF to MB

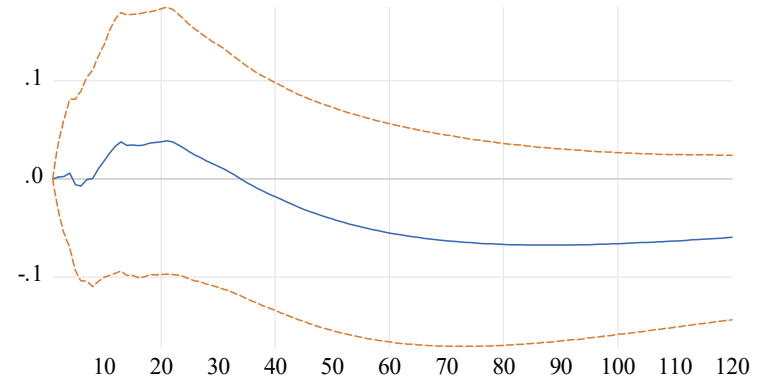

Response of Y to MB

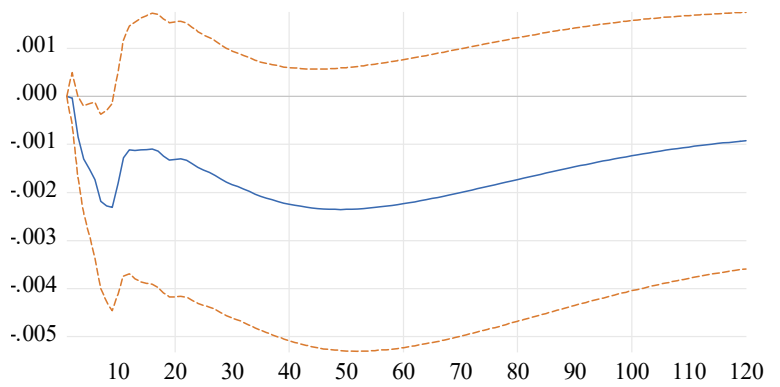

Response of P to MB

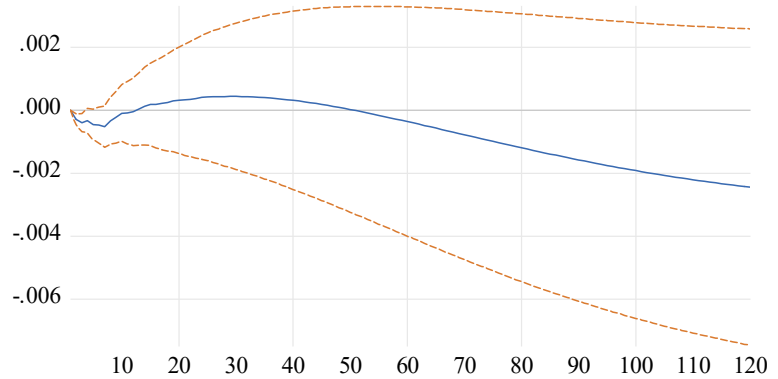

Response of MB to MB

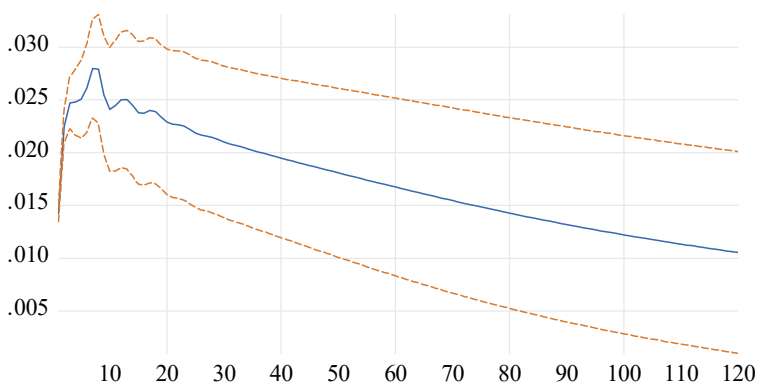

Notes: Solid lines are point estimates and dotted lines are the computed error bands; 95 percent confidence interval bands estimated through a Monte Carlo procedure (1,000 repetitions).

Figure 2: Impulse Response Functions (IRFs), 1959M01-2007M12

Response of FF to MB
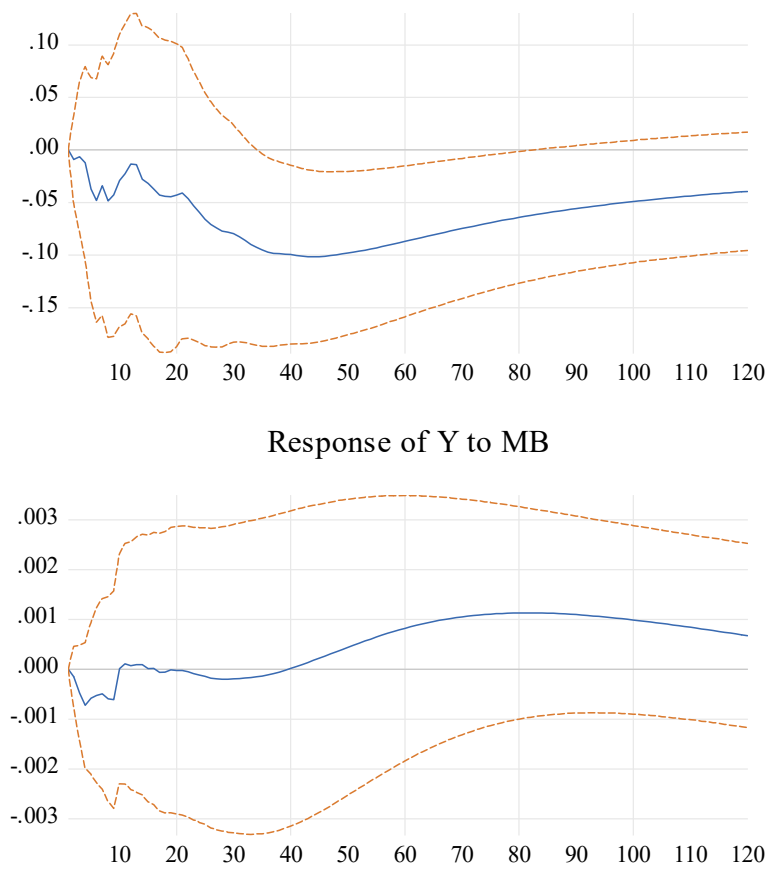

Response of $\mathrm{P}$ to $\mathrm{MB}$

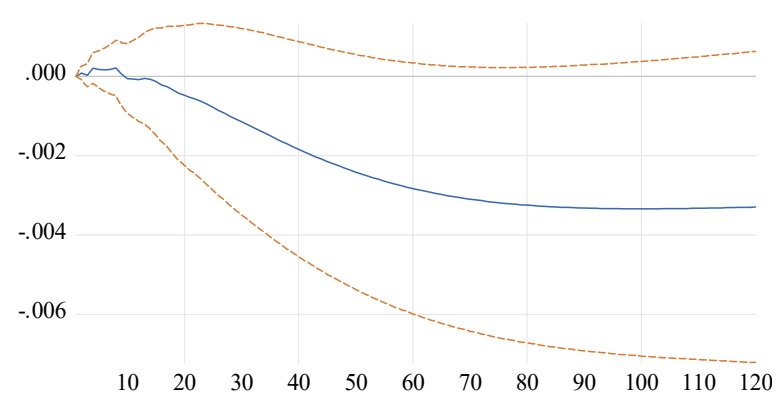

Response of MB to MB

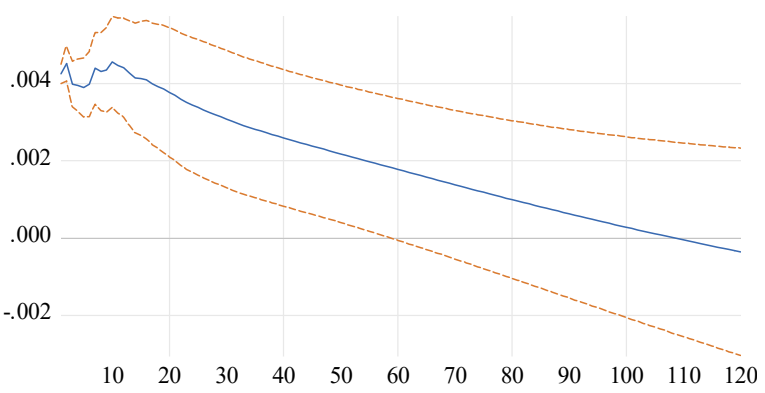

Notes: Solid lines are point estimates and dotted lines are the computed error bands; 95 percent confidence interval bands estimated through a Monte Carlo procedure (1,000 repetitions). 


\section{MMT AND THE OPEN ECONOMY}

The inflation mechanisms explained in section 3 do not consider problems related to the degree of openness of an economic system to international trade of goods and financial asset. This is partly related to the fact that MMT analysis of open economy issues is relatively scarce. MMTers think that a floating exchange rate regime is necessary for a currency to be sovereign. That is why they promote the adoption of this kind of institutional arrangement. But once this condition is held, the theory seems to suggest that there is no external constraint on the economic policy of a country apart from self-imposed limitation (Vergnhanini and De Conti 2018).

The first reason behind this kind of attitude is that there is no clear MMT theory on exchange rate determination. In chapter 24 of Mitchell, Wray, and Watts (2019) ("Policy in an open economy: exchange rates, balance of payments and competitiveness"), a simple model for exchange rate determination based on the trade balance is presented. The problem with this model is twofold:

1. As it is devised, it is incompatible with the aggregate expenditure model, which is assumed throughout the book as the "benchmark" macro model. If the real exchange rate enters the import and export equations without lags, the system is always in a trade balance thanks to the fluctuation of the currency; if the real exchange is input with a lag, the exchange rate tends to explode to infinite (zero) values due to the persistence of the trade surplus (deficit).

2. The model is dismissed by the authors themselves when they state that "the simple supply and demand approach presented in this section really cannot explain exchange rate determination in the real world. The most important flaw in this approach is the focus on international trade in goods and services. In reality, financial transactions are many orders of magnitude greater" (Mitchell, Wray, and Watts 2019, 381). 
Strangely, this approach is even attributed to "mainstream economists," while "the alternative approach follows Keynes's theory, which focuses on asset market" (Mitchell, Wray, and Watts $2019,382)$. Then the covered interest parity theory is presented as the "Keynesian approach."

This classification is at least arguable. Economists that follow the Keynesian school often disagree on exchange rate determination theories. However, it is surely part of the Keynesian approach to the so-called "Harrodian open economy tradition" that "puts a substantial amount of weight on the trade flows" in the determination of exchange rates (Lavoie 2015, 493). The model presented in this paper (see next section) follows the Harrodian tradition in modeling the external position of a country and determining the impact of current account deficit (surplus) on the value of a currency.

The second reason why no external constraints seem to be assumed by MMT theorists lies in their confidence toward the liquidity of foreign exchange markets. This is quite a brave hypothesis for countries and currencies low in the hierarchical international monetary and financial system. In case of a current account deficit, "the 'virtue' of flexible exchange rates seems to be predicated on the notion that the foreign exchange market will quickly find a new lower clearing price as demand for a currency falls, but in many DEC [developing and emerging countries] quantity constraints might prove tremendous: if foreigners and domestic agents [of a DEC running and external deficit] want to exchange domestic currency for US dollars, it will take a mighty fall in the price of domestic currency to stimulate any actor to buy it" (Bonizzi, Kaltenbrunner, and Mitchell 2019, 47). Moreover, in most extreme cases, both foreign nationals and domestic agents can refuse to accept the domestic currency (Bonizzi, Kaltenbrunner, and Mitchel 2019).

While we agree with Bonizzi, Kaltenbrunner, and Mitchel that this represents a pretty solid constraint for DEC countries; we argue that even for the world's major currencies (that are not the dollar) an external deficit position does pose some problems - its inflationary consequences being the most relevant. 
This should not discourage governments from making use of fiscal policy to achieve their aims. The model presented in the following section differs from most mainstream approaches to open economy models because it demonstrates the effectiveness of fiscal policy even in the context of a relatively open economy with flexible exchange rates. However, the viewpoint of MMTers that inflation can actually be ruled out through measures like the JG program is challenged if one considers the impact of exchange rate devaluation on import prices and, via import prices, on domestic prices.

\section{AN MMT "FISCAL EXPANSION" IN AN OPEN ECONOMY SFC MODEL}

One of the most original and valuable characteristics of the MMT handbook is that it explains the national accounts from a sectoral balance perspective in line with the work of Godley. MMT, as many other Post-Keynesian strands of research in the path of the so-called New Cambridge approach, recognizes that flows feed stocks and the latter feed back into the dynamics of the flows of an economic system. For this reason, an SFC model seems the most appropriate framework to test fiscal policy conducted along with the prescriptions of MMT in an open economy context.

The model presented here - the MTO model - builds on the basic structure of the OPENFLEX model featured in Godley and Lavoie (2007). The latter constitutes the "center of gravity of the open economy SFC literature" (Nikiforos and Zezza 2017, 1220).

As the OPENFLEX model, ours is a two-country SFC open economy model with flexible exchange rates. We have seen in section 2 that a floating exchange rate regime is essential to qualify a currency as sovereign. For explanatory purposes, we have called the two countries/blocks United Kingdom (UK) and European Union (EU). The UK is for MMTers an example of a country with full monetary sovereignty. However, the pound sterling $(\mathfrak{E})$ is not the dollar: its position in the international hierarchy of currencies is relatively high, but it has a very limited role as an international reserve and means of payment. 
All the parameters, ${ }^{11}$ variables, equations, and matrices of the MTO model are presented in appendix B.

Conversely to the OPENFLEX, the MTO includes a sector of commercial banks that is essential for recreating the narrative of a hypothetical MMT world in which the (UK) government increases its expenditure to implement a JG program and the treasury is initially funded directly by (UK) central bank. ${ }^{12}$

At the beginning (period 0) all the stocks of the model are set at zero. The accumulation of income and wealth is triggered by the first act of spending by the two governments/blocks. ${ }^{13}$ This is consistent with MMT's contention that "government must spend (or lend) the currency into the economy before taxpayers can pay taxes in the form of the currency. Spend first, tax later is the logical sequence" (Mitchell, Wray, and Watts 2019, 323).

Once that the model reaches the steady-state, it is ready to be "shocked" with a variation of UK government spending for the JG program to test its inflationary effects. Indeed, total government expenditure $\left(g^{£}\right)$ is given by the sum of a conventional, "base," component ( $\left.g_{\text {base }}^{£}\right)$ and a JG component $\left(g_{j g}^{E}\right)$ :

$$
g^{£}=g_{\text {base }}^{£}+g_{j g}^{£}
$$

\footnotetext{
${ }^{11}$ As the MTO is a theoretical model, most of parameters are borrowed by the OPENFLEX. "Reasonable values" have been given to the parameters of the new equations. However, sensitivity tests have been conducted to the check the robustness of the results of the simulations presented in the paper to changes in the values of parameters. From a quantitative perspective, the key parameters that affect the results of the simulations (in terms of change in GDP, change in prices, devaluation of the currency, etc.) are: 1$)$ the constants of import and export equations ( $\varepsilon_{0}$ and $\mu_{0}$ in eqs. 13 and 14). The values of the constants have been set to obtain a volume of UK imports from the EU equal to 16 percent of UK GDP, which approximates the actual average in recent years; 2) The elasticities of the import and export volumes with respect to the GDP of the countries ( $\varepsilon_{2}$ and $\mu_{2}$ in eqs. 13 and 14); and 3 ) The coefficients of the exchange rate pass-through to import and export prices ( $v_{1}$ and $u_{1}$ in eqs. 39 and 40$)$. From a qualitative perspective (direction of change of the variables), the results of the simulations are independent from the values of these parameters (as far as they are kept in a realistic and reasonable range).

${ }^{12}$ As we have seen in section 2, nothing changes in the outcome ex post if we rule out a direct purchase of treasury bills by the central bank as far as we can assume a sufficient demand for treasury debt by the private sector (commercial banks and savers). In turn, this assumption can easily hold as long as the central bank intervenes in the secondary market. A strength of the MTO model is represented by the fact that different narratives can be deployed with the same system of equations because the latter captures the outcome at the end of each period.

${ }^{13}$ For sake of simplicity in the MTO model, the European governments are consolidated into a single entity.

${ }^{14} \mathrm{We}$ are following the numbering of the equations in appendix B, where the whole list of equations is presented.
} 
Let's assume the UK government wants to implement a project with the cost of $£ 2$ billion. It sells government bills to the UK central bank. The treasury's account at the central bank is credited by $£ 2$ billion. When the government hires JG workers, £2 billion are transferred to the (private) bank accounts of these workers and the reserves of the commercial banks at the central bank are credited by $£ 2$ billion. Some of these reserves are used to provide cash to bank account holders. Some are assumed to be set aside to respect the target reserves-deposits ratio (10 percent in the model ${ }^{15}$ ). Even so, at this point there is an excess of reserves held by commercial banks. If the central bank wants to keep control of the interest rate target it must drain the glut of reserves from the system by selling government bills to the commercial banks. In any case, banks are assumed to always be willing to invest reserves in the purchase of government bills because of the differential between the yield of these securities and the deposit rate (which in the MTO model is zero). That is why the quantity of government bills held by the UK banking sector $\left(B_{\text {bank }}^{€}\right)$ always ends up to be the difference between the deposits of UK citizens $\left(D E P_{\text {bank }}^{£}\right)$ and the reserves $\left(R E S^{£}\right)$ :

$$
B_{\text {bank }}^{£}=D E P_{\text {bank }}^{£}-R E S^{£}
$$

Obviously, in the case of the $£ 2$ billion project, the increase in government bills held by the UK banking sector $\left(\Delta B_{b a n k}^{£}\right)$ is nothing but the difference between the variation in UK citizens' deposits $\left(\triangle D E P_{\text {bank }}^{€}\right)$ and the variation in reserves $\left(\Delta R E S^{£}\right)$.

The currency emission (monetary base) generated by the policy is not given by the $£ 2$ billion initially credited to the government account at the central bank, but by the additional monetary base $\left(\Delta H_{S}^{£}\right)$ left in the system at the end of this cycle of operations:

$$
\Delta H_{s}^{€}=\Delta H_{h}^{£}+\Delta R E S^{£}
$$

\footnotetext{
15 That's an arbitrary value, as in UK there is no legal reserve requirement. However, nothing changes in the dynamics.
} 
Both $\Delta H_{h}^{€}$ (additional cash held by UK citizens) and $\triangle R E S^{£}$ are ultimately determined by the choices of UK households on how they want to allocate the additional saving generated in the system by the government deficit and its multiplier effect.

The mechanism captured by the equations above (together with the MTO model's other equations) gives shape to the idea that there is no "ex ante decision of treasury to either borrow or print money," rather "it is an ex post [...] outcome [...] determined by decisions made by households, firms, financial institutions, the central bank and even foreign investors" (Mitchell, Wray, and Watts 2019, 335).

With respect to the structure of prices, the MTO model encompasses a slightly more advanced arrangement in comparison with OPENFLEX. Domestic inflation is not measured via the GDP deflator anymore. A mark-up $\left(\varphi^{£}\right)$ rule on unit costs $U C^{£}$ is used for the price level of the goods "made in Britain" $\left(p_{\text {madeUK }}^{£}\right)$ :

$$
p_{\text {madeUK }}^{£}=\left(1+\varphi^{£}\right) U C^{£}
$$

Other equations set the price (index) of: UK imports (eq. 39), UK exports (eq. 40), UK total sales (eq. 45), and UK domestic sales (import included, eq. 47).

One of the key assumptions behind the MMT's representation of the labor market is that government's intervention as an employer of last resort does not put upward pressure on the wages of the non-JG workers. First, "there might be little perceived difference between unemployment and a JG job for a highly paid worker," and, second, "JG workers would constitute a more credible threat to the current private sector employees than say, the long-term unemployed" (Mitchell, Wray, and Watts 2019, 304). This assumption is captured in equations 51-60 of the MTO model (see appendix B). The wage rate of the "private sector"16 $\left(W^{£}\right)$ depends on a "standard" component $\left(W_{S}^{£}\right)$ and a rate of increase $\left(W_{i n c}^{\in}\right)$. The latter is driven by a

\footnotetext{
${ }^{16}$ We have used the expression "private sector" for the sake of simplicity. In more advanced versions of the model, a distinction could be made between workers hired by private firms and public employees/civil servants, meaning workers hired by the government but not within the JG program.
} 
fictional unemployment rate $\left(U N_{p}^{€}\right)$ that does not count JG workers as employed. When $U N_{p}^{€}$ goes below a certain threshold (winf $f^{£ 17}$ ), the mechanism that fuels incremental changes in the wage rate is triggered. This means that JG workers cannot directly impact the level of wages of the private sector. The JG program can impact $W^{£}$ only as far as it contributes to a higher level of employment in our private sector.

Now we can test the effects of a JG program. In 2020, the UK government invests $£ 2$ billion in the $g_{j g}^{£}$ component, which was set at 0 in the baseline. Figure 3 shows the behavior of the system of prices after the implementation of the policy, as well as the level of employment. Note that in the baseline scenario (steady-state), inflation is equal to zero, as all prices are constant.

\section{Figures 3a: UK Prices Following the Implementation of a JG Program}

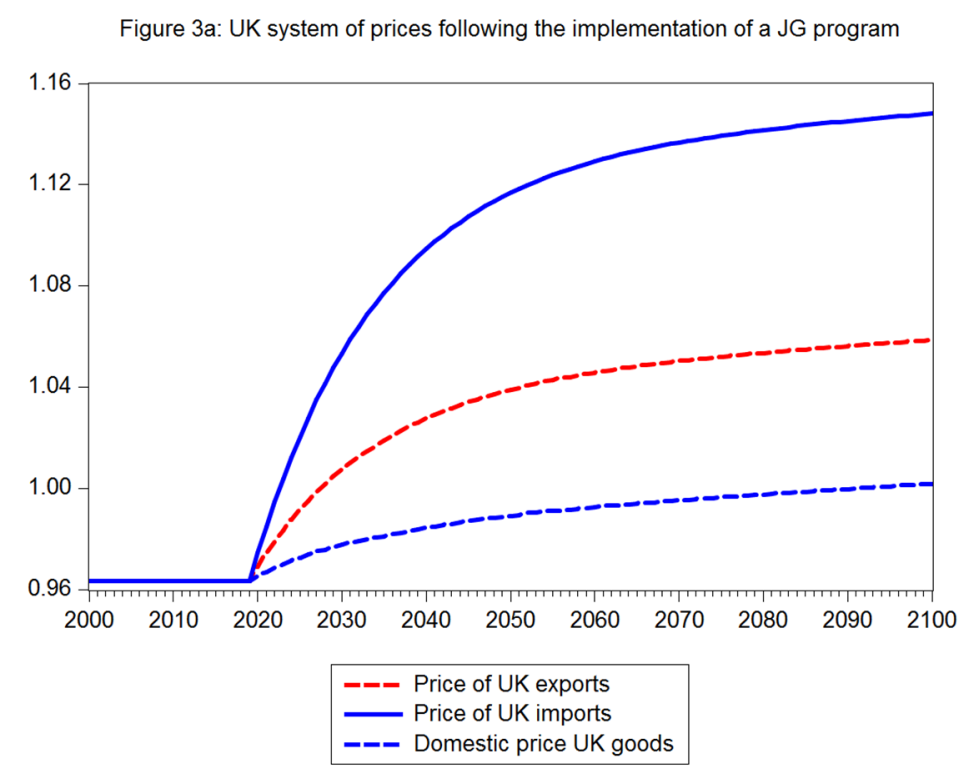

${ }^{17}$ winf $^{£}$ has been initially set at 5.5 percent. Of course, the lower winf $f^{£}$ is, the lower the wage inflationary pressure will be. 


\section{Figure 3b: UK Employment Following the Implementation of a JG Program}

Figure 3b: Effect on UK total employment of the implementation of a JG program

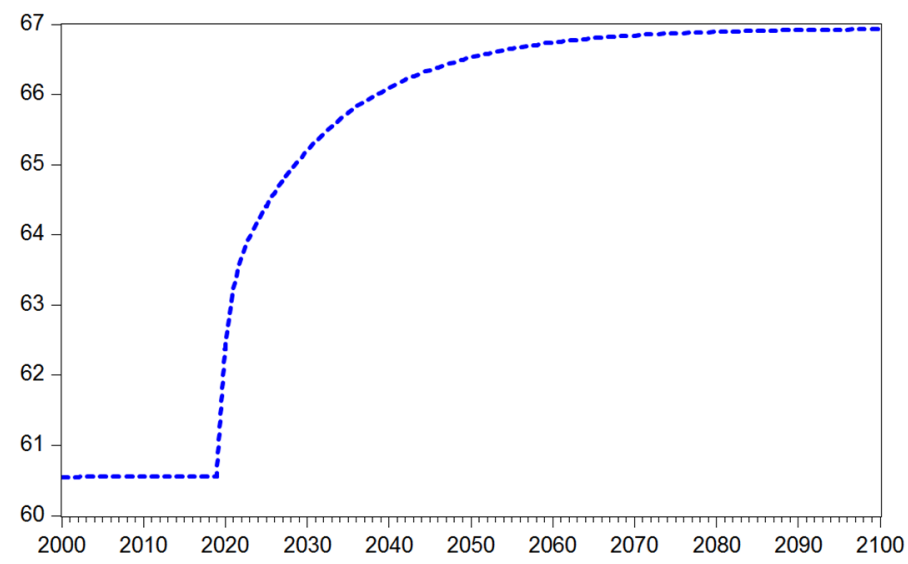

As it is evident from figure 3a, all price indexes increase after the shock and they continue to grow for several periods. The inflation phenomenon is firstly linked to the current account deficit, which is originated by the expansionary fiscal policy. The external deficit put downward pressure on the pounds, as the increase in the demand for euros is not matched by an equal increase in the demand for pounds. In turn, the depreciation of the pound affects export and import prices. Domestic prices rise, as import prices are a component of them. Note that the model tends to underestimate the impact of currency devaluation on domestic prices for two reasons: 1) For sake of simplicity, the MTO is a pure "labor economy." There are no (imported) intermediate goods that enter the production process and therefore the increase in import prices in the UK does not affect the price of UK's domestically manufactured merchandise; and 2) For the sake of realism, the model assumes a partial pass-through of the exchange rate to import (and export) prices as a certain degree of strategic behavior by EU (and UK) exporters cannot be ruled out. A partial pass-through is a necessary condition for the stability of SFC open economy model, too (Carnevali et al. 2020).

Table B1 in appendix B reports different levels of increases in domestic prices 20 periods after the fiscal expansion given different sets of parameters. In every case, the JG program implementation is followed by a long-lasting depreciation of the currency and domestic inflation. 
There is also a second component that contributes to the rise in prices. Although we have seen that wage inflation is only linked to a "fictional" unemployment rate $\left(U N_{p}^{f}\right)$, which does not count JG workers as "employed," the implementation of a JG program put money in the pockets of formerly unemployed people. These people, in turn, spend the money in the private sector, which has to hire more workers to keep up with the level of higher demand. Therefore, unemployment in the private sector decreases, as shown in figure 4.

\section{Figure 4: UK Unemployment Rate Following the Implementation of a JG Program}

Figure 4: Effect on UK unemployment of the implementation of a JG program

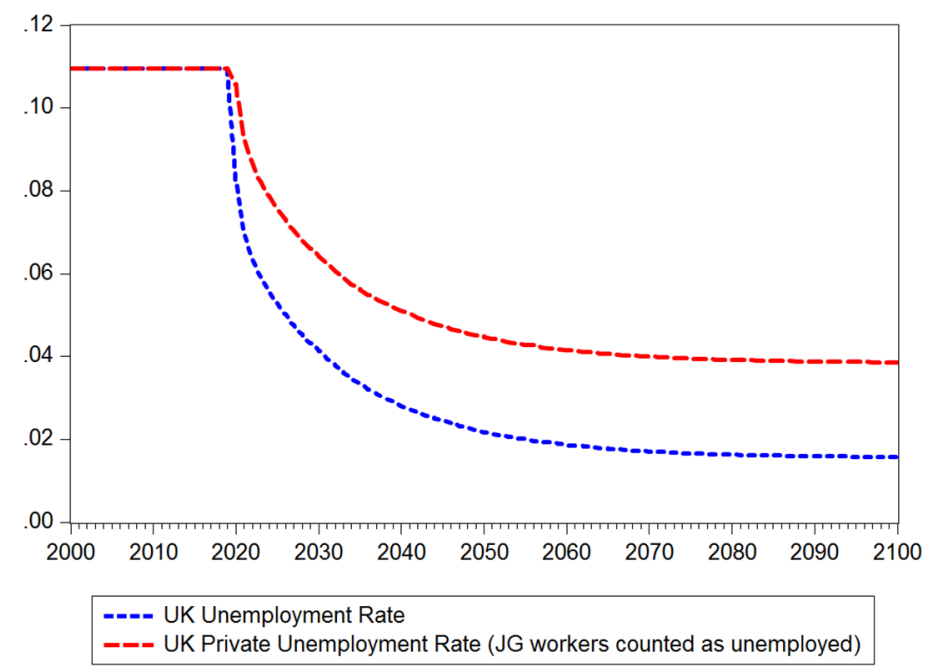

The precise impact of lower "private" unemployment on wages, and on prices, will depend on the parameters chosen in equations 51-60. When $\operatorname{winf}^{\epsilon}$ is chosen low enough (e.g., 0.035) to avoid wage increases due to low private employment, the MTO model can show the pure effect of the currency devaluation channel (see figure 5). 


\section{Figure 5: UK System of Prices Following the Implementation of a JG Program}

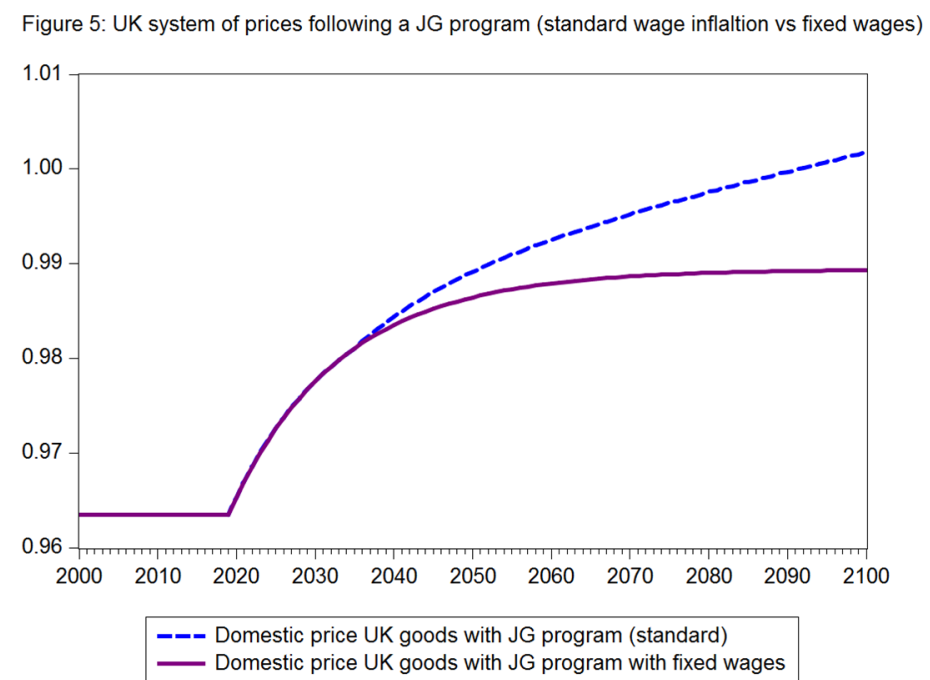

Notes: Standard wage inflation parameter $(0.055)$ vs low wage inflation parameter $(0.035$. This brings about fixed wages as the "fictional" unemployment rate never goes below 3.5 percent in the simulations).

Simulations conducted with the MTO show that even in a relatively open economy with flexible exchange rates, expansionary fiscal policy that takes the form of a JG program can be very effective in boosting the level of employment as far as there is spare production capacity in the system. The JG is supposed to buy labor off the bottom and therefore it should not put pressure on wages, even when the economy approaches full employment. However, it seems that the trade-off between inflation and employment cannot be completely bypassed. First of all, inflation is imported via the external channel. That's not necessarily bad news. The depreciation of the currency is at the core of the rebalancing mechanism that allows the UK to stabilize the trade deficit and close the current account deficit in the medium-to-long run despite the permanent higher level of income and employment. Secondly, the JG program boosts employment even in the private (non-JG) sector, and this can be a second channel of inflation transmission through higher wages.

The Philips curve, that in an MMT world was thought to be tamed into a flat line thanks to the JG program, still looms in its very original "policy menu" form. ${ }^{18}$

\footnotetext{
${ }^{18}$ That is to say, it is a summary of the different combinations of inflation and unemployment at the disposal of the policymaker, who cannot completely avoid dealing with the trade-off between these two issues.
} 


\section{CONCLUSIONS}

In 2013, Marc Lavoie published a paper titled "The Monetary and Fiscal Nexus of NeoChartalism: A Friendly Critique" (emphasis added). Our paper shares the same purpose of developing a friendly critique. This time the critique is directed to the Neo-Chartalist theory of inflation from an open economy perspective. We appreciate the role played by the MMT project - especially in the United States - to relaunch the debate on the use of fiscal policy to fight against unnecessary unemployment. We also think that MMT theorists' effort to also address nonspecialist readers should be credited for improving the pluralism of democratic public debate, too often dominated by unquestioned mainstream-neoclassical economic dogmas. We agree with MMT theorists that fears of a hyperinflation, Weimar-style tragedy that are put forward by some of their critics are often misplaced. And we have provided empirical evidence in support of this countercriticism.

However, from an open economy perspective, the "inflation challenge" cannot be overlooked even in an ideal MMT world, where a JG program is assumed to be implemented with the support of an active central bank.

With the use of a SFC open economy model, we have tested MMT's claim that it is possible to simultaneously obtain a dramatic increase in employment and a flat Phillips curve, as long as we deal with a country whose currency is fully sovereign. Our simulations show that some degree of trade-off between inflation and (un)employment is unavoidable in a flexible exchange regime. 


\section{REFERENCES}

Bonizzi, B., A. Kaltenbrunner, and J. Mitchell. 2019. "Monetary sovereignty is a spectrum: modern monetary theory and developing countries." Real-World Economics Review 89: $46-61$.

Carnevali, E., G. Fontana, and M. Veronese Passarella. 2020. "Assessing the Marshall-Lerner Condition within a stock-flow consistent Model." Cambridge Journal of Economics 44(4): 891-918.

Deleidi, M. 2019. "Endogenous money theory: horizontalist, structuralist and the credit market." Bulletin of Political Economy 13(1): 21-53.

— 2020. "Post-Keynesian endogenous money theory: Horizontalists, structuralists and the paradox of illiquidity." Metroeconomica 71(1): 156-75.

Deleidi, M., and E. S. Levrero. 2019. "The money creation process: A theoretical and empirical analysis for the United States." Metroeconomica 70(4): 552-86.

Godley, W., and M. Lavoie. 2007. Monetary Economics: an integrated approach to credit, money, income, production and wealth. London: Palgrave Macmillan.

Innes, A. M. 1913. “What Is Money?” Banking Law Journal 30(5): 377-408. 1914. "The Credit Theory of Money." Banking Law Journal 31(1): 151-68.

Kalecki, M. 1943. "Political aspects of full employment." The Political Quarterly 14(4): 322-30.

Kilian, L., and H. Lütkepohl. 2017. Structural vector autoregressive analysis. Cambridge, UK: Cambridge University Press.

Knapp, G. F. 1924. The State Theory of Money. Clifton, NJ: Augustus M. Kelley.

Keynes, J. M. (1930) 2011. A Treatise on Money. 2011 edition. Eastford, CT: Martino Fine Books.

—. (1936) 2017. The General Theory of Employment, Interest and Money. Ware, UK: Wordsworth Editions.

— 1940. How to pay for the war: a radical plan for the Chancellor of the Exchequer. London: Macmillan.

Kregel, J. 2019. "MMT: the wrong answer to the wrong question." Real-World Economics Review 89: 85-96. 
Lavoie, M. 1996. "Horizontalism, structuralism, liquidity preference and the principle of increasing risk." Scottish Journal of Political Economy 43(3): 275-300.

— 2013. "The Monetary and Fiscal Nexus of Neo-Chartalism: A Friendly Critique." Journal of Economic Issues XLVII(1): 1-31.

—. 2015. Post-Keynesian economics. New foundations. Cheltenham, UK: Edward Elgar.

Lerner, A. 1943. "Functional finance and the federal debt." Social Research 10(1): 38-51.

Lütkepohl, H. 2005. New introduction to multiple time series analysis. New York: Springer Science \& Business Media.

Mankiw, G. 2020. “A Skeptic's Guide to Modern Monetary Theory.” AEA Papers and Proceedings 110: 141-44.

Mitchell, W., L. R. Wray, and M. Watts. 2019. Macroeconomics. London: Macmillan-Red Globe Press.

Nikiforos, M., and G. Zezza. 2017. "Stock-Flow-Consistent Macroeconomic Models: A Survey." Journal of Economic Surveys 31(5): 1204-39.

Phillips, A. W. 1958. "The relation between unemployment and rate of change of money wage rates in the United Kingdom, 1861-1957." Economica 25(100): 283-99.

Piketty, T. 2014. Capital in the Twenty-First Century. Cambridge, MA and London: The Belknap Press of Harvard University Press.

Rochon, L. P. 1999. Credit, money, and production: An alternative post-Keynesian approach. Cheltenham, UK: Edward Elgar.

_ 2001. "Horizontalism: Setting the record straight." In L. P. Rochon and M. Vernengo (eds.), Credit, interest rates and the open economy: Essays on horizontalism. Cheltenham, UK: Edward Elgar.

—. 2019. "MMT and TINA." Real-World Economics Review 89: 156-66.

Samuelson, P., and R. Solow. 1960. "Analytical aspects of anti-inflation policy." The American Economic Review 50(2): 177-94.

Tankus, N. 2018. "Monetary Sovereignty and Our Dollar World." Manchester International Law Centre Speaker Series, June 6. Available at: https://www.youtube.com/watch?v=xZnEDrVfcHU 
Tymoigne, E., and L. R. Wray. 2013. "Modern Money Theory 101: A Reply to Critics.” Levy Institute Working Paper No. 778. Annandale-on-Hudson, NY: Levy Economics Institute of Bard College.

Vergnhanini, R., and B. De Conti. 2018. "Modern Monetary Theory: A Criticism from the Periphery." Brazilian Keynesian Review 3(2): 16-31.

Wray, L. R. 2019. "Alternative paths to modern money theory." Real-World Economics Review 89: 5-22. 


\section{APPENDIX A}

\section{List of Variables}

St. Louis Adjusted Monetary Base, Billions of Dollars, Monthly, Seasonally Adjusted. https://fred.stlouisfed.org/series/AMBSL (MB)

Consumer Price Index for All Urban Consumers: All Items in U.S. City Average, Index 19821984=100, Monthly, Seasonally Adjusted.

https://fred.stlouisfed.org/series/CPIAUCSL (P)

Effective Federal Funds Rate, Percent, Monthly, Not Seasonally Adjusted.

https://fred.stlouisfed.org/series/FEDFUNDS (FF)

Industrial Production Index, Index 2012=100, Monthly, Seasonally Adjusted.

https://fred.stlouisfed.org/series/INDPRO (Y)

\section{Table A1: Lag Order Selection, Akaike Information Criterion (AIC)}

\begin{tabular}{|c|c|}
\hline Lag & AIC \\
\hline 0 & 6.47645 \\
\hline 1 & -19.96895 \\
\hline 2 & -20.71291 \\
\hline 3 & -20.80939 \\
\hline 4 & -20.81259 \\
\hline 5 & -20.81982 \\
\hline 6 & -20.81391 \\
\hline 7 & -20.7967 \\
\hline 8 & -20.8184 \\
\hline 9 & -20.83102 \\
\hline 10 & $-20.84942 *$ \\
\hline 11 & -20.84583 \\
\hline 12 & -20.83322 \\
\hline
\end{tabular}

Note: Table A1 suggests that the optimum lag is 10 and, in table A2, the estimated VAR satisfies the stability condition, as no root lies outside the unit circle. 
Table A2: Roots of Characteristic Polynomial

\begin{tabular}{|c|c|}
\hline Root & Modulus \\
\hline $0.997985-0.001705 i$ & 0.997986 \\
\hline $0.997985+0.001705 i$ & 0.997986 \\
\hline $0.977646-0.023229 i$ & 0.977922 \\
\hline $0.977646+0.023229 i$ & 0.977922 \\
\hline 0.878778 & 0.878778 \\
\hline $0.875973-0.057994 i$ & 0.877891 \\
\hline $0.875973+0.057994 i$ & 0.877891 \\
\hline $0.695645+0.531504 i$ & 0.875453 \\
\hline $0.695645-0.531504 i$ & 0.875453 \\
\hline $0.168687+0.844703 i$ & 0.861382 \\
\hline $0.168687-0.844703 i$ & 0.861382 \\
\hline $0.287958-0.805013 i$ & 0.854965 \\
\hline $0.287958+0.805013 i$ & 0.854965 \\
\hline $0.630568+0.567313 i$ & 0.848210 \\
\hline $0.630568-0.567313 i$ & 0.848210 \\
\hline$-0.501079-0.678946 i$ & 0.843830 \\
\hline$-0.501079+0.678946 i$ & 0.843830 \\
\hline$-0.780170+0.233542 i$ & 0.814375 \\
\hline$-0.780170-0.233542 i$ & 0.814375 \\
\hline$-0.340462+0.731774 i$ & 0.807098 \\
\hline$-0.340462-0.731774 i$ & 0.807098 \\
\hline $0.204251-0.754180 i$ & 0.781349 \\
\hline $0.204251+0.754180 i$ & 0.781349 \\
\hline-0.779425 & 0.779425 \\
\hline$-0.331816-0.701523 i$ & 0.776039 \\
\hline$-0.331816+0.701523 i$ & 0.776039 \\
\hline $0.672403-0.359066 i$ & 0.762269 \\
\hline $0.672403+0.359066 i$ & 0.762269 \\
\hline$-0.654727-0.338295 i$ & 0.736960 \\
\hline$-0.654727+0.338295 i$ & 0.736960 \\
\hline $0.496085-0.507795 i$ & 0.709899 \\
\hline $0.496085+0.507795 i$ & 0.709899 \\
\hline$-0.094214+0.701335 i$ & 0.707635 \\
\hline$-0.094214-0.701335 i$ & 0.707635 \\
\hline$-0.631798-0.134495 i$ & 0.645955 \\
\hline$-0.631798+0.134495 i$ & 0.645955 \\
\hline$-0.336958+0.523143 i$ & 0.622270 \\
\hline$-0.336958-0.523143 i$ & 0.622270 \\
\hline 0.580882 & 0.580882 \\
\hline 0.139940 & 0.13994 \\
\hline & \\
\hline
\end{tabular}




\section{APPENDIX B}

Table B1: Sensitivity Test: Change in UK Domestic Prices 20 Periods after the Implementation of JG Program

\begin{tabular}{|c|c|c|c|c|c|c|c|}
\hline$v_{1}$ & $u_{1}$ & $\varepsilon_{0}$ & $\mu_{0}$ & $\varepsilon_{2}$ & $\mu_{2}$ & winf $^{f}$ & \% Change in Domestic Prices \\
\hline 0.8 & 0.4 & -1.8 & -1.8 & 1 & 1 & 0.055 & $2.10 \%$ \\
\hline 0.8 & 0.4 & -1.8 & -1.8 & 0.9 & 0.9 & 0.055 & $1.03 \%$ \\
\hline 0.8 & 0.4 & -1.8 & -1.8 & 1.1 & 1.1 & 0.055 & $4.30 \%$ \\
\hline 0.8 & 0.4 & -1.8 & -1.8 & 1.2 & 1.2 & 0.055 & $9.64 \%$ \\
\hline 0.8 & 0.4 & -2 & -2 & 1 & 1 & 0.055 & $1.58 \%$ \\
\hline 0.8 & 0.4 & -1.6 & -1.6 & 1 & 1 & 0.055 & $2.77 \%$ \\
\hline 0.8 & 0.4 & -1.8 & -1.8 & 1 & 1 & 0.035 & $2.03 \%$ \\
\hline 0.8 & 0.4 & -1.8 & -1.8 & 1 & 1 & 0.065 & $2.22 \%$ \\
\hline 0.9 & 0.3 & -1.8 & -1.8 & 1 & 1 & 0.055 & $2.90 \%$ \\
\hline 0.7 & 0.5 & -1.8 & -1.8 & 1 & 1 & 0.055 & $1.49 \%$ \\
\hline
\end{tabular}

Note: Results for different sets of parameters. 
Table B2: MTO Model Transactions-Flow Matrix

\begin{tabular}{|c|c|c|c|c|c|c|c|c|c|c|c|c|}
\hline & UK House. & UK Firms & UK Banks & UK Gov. & UK C.B. & & EU House. & EU Firms & EU Banks & EU Gov. & EU C. B. & Sum \\
\hline & \multicolumn{5}{|c|}{ all in $£$} & Exch. rate & \multicolumn{5}{|c|}{ all in $€$} & \\
\hline Consumption & $-C^{E}$ & $+C^{£}$ & & & & & $-C^{€}$ & $+C^{€}$ & & & & 0 \\
\hline Gov. Expend. & & $+G^{E}$ & & $-G^{E}$ & & & & $+G^{€}$ & & $-G^{€}$ & & 0 \\
\hline \multirow[t]{2}{*}{ Trade } & & $-I M^{£}$ & & & & $x r^{E}$ & & $-I M^{€}$ & & & & 0 \\
\hline & & $+X^{£}$ & & & & $x r^{£}$ & & $+X^{€}$ & & & & 0 \\
\hline GDP/Income & $+Y^{£}$ & $-Y^{\epsilon}$ & & & & & $+Y^{€}$ & $-Y^{€}$ & & & & 0 \\
\hline Taxes & $-T^{£}$ & & & $+T^{E}$ & & & $-T^{€}$ & & & $+T^{€}$ & & 0 \\
\hline \multirow[t]{2}{*}{ Interest paym. } & $+r^{E} B_{€}^{£}$ & & $+r^{E} B_{\text {bank }}^{E}$ & $-r^{£} B^{£}$ & $+r^{£} B_{c b £}^{£}$ & $x r^{E}$ & $+r^{€} B_{€}^{\epsilon} x r^{€}$ & & $+r^{€} B_{\text {bank }}^{€}$ & & & 0 \\
\hline & $+r^{\$} B_{\$}^{\$} x r^{\$}$ & & & & & $x r^{E}$ & $+r^{€} B_{€}^{€}$ & & & $-r^{€} B^{€}$ & $+r^{€} B_{c b €}^{€}$ & 0 \\
\hline Bank profits & $+F_{\text {bank }}^{E}$ & & $-F_{\text {bank }}^{£}$ & & & & $+F_{\text {bank }}^{€}$ & & $-F_{\text {bank }}^{€}$ & & & 0 \\
\hline CB profits & & & & $+F_{c b}^{£}$ & $-F_{c b}^{E}$ & & & & & $+F_{c b}^{€}$ & $-F_{c b}^{€}$ & 0 \\
\hline \multicolumn{13}{|c|}{ Flows of funds (changes in assets) } \\
\hline Money & $-\Delta H_{h}^{E}$ & & & & $+\Delta H_{h}^{E}$ & & $-\Delta H_{h}^{€}$ & & & & $+\Delta H_{h}^{€}$ & 0 \\
\hline$£$ Bills & $-\Delta B_{€}^{£}$ & & $-\Delta B_{\text {bank }}^{£}$ & $+\Delta B^{£}$ & $-\Delta B_{c b £}^{£}$ & $x r^{E}$ & $-\Delta B_{€}^{£} x r^{£}$ & & & & & 0 \\
\hline$€$ Bills & $-\Delta B_{€}^{€} x r^{€}$ & & & & & $x r^{E}$ & $-\Delta B_{€}^{€}$ & & $-\Delta B_{\text {bank }}^{€}$ & $+\Delta B^{€}$ & $-\Delta B_{c b €}^{€}$ & 0 \\
\hline Bank Deposits & $-\Delta D E P_{\text {bankd }}^{£}$ & & $+\Delta D E P_{\text {bank }}^{£}$ & & & & $-\triangle D E P_{\text {bankd }}^{€}$ & & $+\Delta D E P_{\text {bank }}^{€}$ & & & 0 \\
\hline Bank Reserves & & & $-R E S^{£}$ & & $+R E S^{£}$ & & & & $-R E S^{€}$ & & $+R E S^{€}$ & 0 \\
\hline Sum & 0 & 0 & 0 & 0 & 0 & & 0 & 0 & 0 & 0 & 0 & 0 \\
\hline
\end{tabular}

Table B3: MTO Model Balance Sheet Matrix

\begin{tabular}{|c|c|c|c|c|c|c|c|c|c|c|c|c|}
\hline & UK Households & s UK Firms & UK Banks & UK Government & UK C. B. & & EU Households & EU Firms & EU Banks & EU Government & EU C. B. & Sum \\
\hline & & & all in $£$ & & & Ex. rate & & & all in $€$ & & & \\
\hline Money & $+H_{h}^{£}$ & & & & $-H_{h}^{£}$ & & $+H_{h}^{€}$ & & & & $-H_{h}^{€}$ & 0 \\
\hline$£$ Bills & $+B_{€}^{£}$ & & $+\Delta B_{\text {bank }}^{£}$ & $-B^{E}$ & $+B_{c b £}^{£}$ & $x r^{E}$ & $+B_{€}^{£} x r^{£}$ & & $+\Delta B_{\text {bank }}^{€}$ & & & 0 \\
\hline$€$ Bills & $+B_{€}^{\$} x r^{€}$ & & & & & $x r^{E}$ & $+B_{€}^{€}$ & & & $-B^{€}$ & $+B_{c b €}^{€}$ & 0 \\
\hline Bank Deposits & $+\Delta D E P_{\text {bank }}^{E}$ & & $-\triangle D E P_{\text {bank }}^{E}$ & & & & $+\triangle D E P_{\text {bank }}^{€}$ & & $-\Delta D E P_{\text {bank }}^{€}$ & & & 0 \\
\hline Bank Reserves & & & $+R E S^{£}$ & & $-R E S^{£}$ & $x r^{E}$ & & & $+R E S^{€}$ & & $-R E S^{€}$ & 0 \\
\hline Balance & $-V^{E}$ & & 0 & $-N W_{g}^{E}$ & 0 & $x r^{E}$ & $-V^{€}$ & & 0 & $-N W_{g}^{€}$ & 0 & 0 \\
\hline Sum & 0 & & 0 & 0 & 0 & & 0 & & 0 & 0 & 0 & \\
\hline
\end{tabular}




\section{Variables of the MTO Model}

$Y D^{⿷}=$ Disposable income $\mathrm{UK}$

$Y D^{€}=$ Disposable income EU

$Y^{£}=$ Nominal UK income (GDP at current prices)

$Y^{€}=$ Nominal EU income (GDP at current prices)

$B_{E s}^{\in}=$ UK bills held by UK households

$B_{£ s}^{\in}=$ EU bills held by UK households

$B_{€ s}^{€}=$ EU bills held by EU households

$B_{€ S}^{\in}=$ UK bills held by EU households

$x r^{\epsilon}=$ UK exchange rate (value of the pound in euros)

$x r^{€}=$ EU exchange rate (value of the euro in pounds)

$F_{\text {bank }}^{\epsilon}=$ UK banks' profits

$F_{\text {bank }}^{€}=$ EU banks' profits

$Y D_{h s}^{E}=$ UK households Haig-Simons disposable income (nominal terms)

$Y D_{h s}^{€}=$ EU households Haig-Simons disposable income (nominal terms)

$V^{£}=$ UK households' private wealth

$V^{€}=$ EU households' private wealth

$C^{£}=$ Value of consumption in UK

$C^{€}=$ Value of consumption in EU

$v^{E}=$ UK households' private wealth (real terms)

$v^{€}=$ EU households' private wealth (real terms)

$p_{d s}^{\in}=$ UK prices of domestic sales

$p_{d s}^{€}=$ EU prices of domestic sales

$y d_{h s}^{ \pm}=$UK households Haig-Simons disposable income (real terms)

$y d_{h s}^{€}=$ EU households Haig-Simons disposable income (real terms)

$y d_{h s e}^{€}=$ UK households Haig-Simons expected disposable income (real terms)

$y d_{h s e}^{€}=$ UK households Haig-Simons expected disposable income (real terms)

$p_{m}^{£}=$ UK import prices

$p_{x}^{ \pm}=$UK export prices

$p_{m}^{€}=$ EU import prices

$p_{x}^{€}=$ EU export prices

$p_{\text {madeUK }}^{ \pm}=$Original prices of made in Britain goods

$p_{\text {madeEU }}^{€}=$ Original prices of made in EU goods

$X^{£}=$ UK exports (nominal terms)

$X^{€}=\mathrm{EU}$ exports (nominal terms)

$I M^{E}=\mathrm{UK}$ imports (nominal terms)

$I M^{€}=\mathrm{EU}$ imports (nominal terms)

$x^{E}=$ UK exports (real terms)

$\mathrm{im}^{\epsilon}=\mathrm{UK}$ imports (real terms)

$x^{€}=$ EU exports (real terms)

$\mathrm{im}^{€}=$ EU imports (real terms)

$c^{E}=\mathrm{UK}$ real consumption

$c^{€}=$ EU real consumption 
$S^{£}=$ Value of sales in UK

$S^{€}=$ Value of sales in EU

$s^{E}=$ Total volume of sales in UK

$s^{€}=$ Total volume of sales in EU

$D S^{£}=$ UK domestic sales value

$D S^{€}=$ EU domestic sales value

$d s^{E}=$ UK domestic sales volume

$d s^{€}=$ EU domestic sales volume

$y^{E}=$ Real UK GDP

$y^{€}=$ Real EU GDP

$N^{£}=$ Employment level in UK

$N^{€}=$ Employment level in EU

$N_{\text {full }}^{f}=$ UK Full employment level

$N_{\text {full }}^{€}=$ EU Full employment level

$J G_{n}^{ \pm}=$Workers employed in the UK JG program

$J G_{n}^{€}=$ Workers employed in the EU JG program

$p_{s}^{\in}=$ Average price of all sales in UK

$p_{s}^{€}=$ Average price of all sales in EU

$I N F^{£}=\mathrm{UK}$ inflation rate

$I N F^{€}=$ EU inflation rate

$W^{\epsilon}=$ Actual wage rate in UK

$W^{€}=$ Actual wage rate in EU

$W_{i n c}^{\in}=$ UK Wage increase

$W_{i n c}^{€}=$ EU Wage increase

$F_{W}^{\epsilon}=$ UK wage increase factor

$F_{W}^{€}=$ EU wage increase factor

$W_{S}^{\epsilon}=$ Standard wage rate in $\mathrm{UK}$

$W_{s}^{€}=$ Standard wage rate in EU

$U N_{p}^{\in}=$ Private (non-JG) UK unemployment rate

$U N_{p}^{€}=$ Private (non-JG) EU unemployment rate

$U N^{£}=$ UK unemployment rate

$U N^{€}=$ EU unemployment rate

$W_{\text {incmax }}^{€}=$ Maximum UK Wage increase factor

$W_{\text {incmax }}^{€}=$ Maximum UK Wage increase factor

$B_{£ d}^{£}=$ Demand for UK bills by UK households

$B_{€ d}^{€}=$ Demand for EU bills by UK households

$B_{€ d}^{€}=$ Demand for EU bills by EU households

$B_{€ d}^{\epsilon}=$ Demand for UK bills by EU households

$H_{h}^{\epsilon}=$ Cash held by UK households

$H_{h}^{€}=$ Cash held by EU households

$D E P_{\text {bankd }}^{\epsilon}=$ Demand for bank deposits by UK households

$D E P_{\text {bankd }}^{\epsilon}=$ Demand for bank deposits by EU households

$H_{S}^{€}=$ UK monetary base 
$H_{s}^{€}=$ EU monetary base

$B_{E s}^{£}=$ UK bills held by UK households

$B_{E s}^{\epsilon}=$ EU bills held by UK households

$B_{€ s}^{€}=$ EU bills held by EU households

$B_{€ s}^{\in}=$ UK bills held by EU households

$G^{\in}=$ UK total government expenditure (nominal terms)

$G^{€}=$ EU total government expenditure (nominal terms)

$g^{E}=$ UK total government expenditure (real terms, initial value $=22$ )

$g^{€}=$ EU total government expenditure (real terms, initial value $=22$ )

$g_{j g}^{f}=$ UK Government expenditure for the job guarantee program (real terms)

$g_{j g}^{€}=$ UK Government expenditure for the job guarantee program (real terms)

$g_{\text {base }}^{\in}=\mathrm{UK}$ Base Government expenditure (real terms)

$g_{\text {base }}^{€}=\mathrm{UK}$ Base Government expenditure (real terms)

$T^{E}=$ Taxes paid by UK households

$T^{£}=$ Taxes paid by EU households

$B_{c b £ s}^{\in}=\mathrm{UK}$ bills held by UK central bank

$B_{c b € s}^{€}=$ EU bills held by EU central bank

$F_{c b}^{\in}=$ UK Central Bank's profits

$F_{c b}^{€}=$ EU Central Bank's profits

$B_{S}^{\in}=$ UK public debt (total UK bills issued)

$B_{S}^{€}=$ EU public debt (total EU bills issued)

$D E P_{\text {bank }}^{E}=$ Bank deposits (supply) in UK

$D E P_{\text {bank }}^{\epsilon}=$ Bank deposits (supply) in EU

$B_{\text {bank }}^{£}=\mathrm{UK}$ bills held by UK banks

$B_{\text {bank }}^{€}=$ EU bills held by EU banks

$R E S^{£}=$ UK bank reserves at the UK central bank

$R E S^{€}=$ EU bank reserves at the EU central bank

$P S B R^{E}=\mathrm{UK}$ government deficit

$P S B R^{€}=$ EU government deficit

$N A F A^{£}=$ UK households' net accumulation of financial assets

$N A F A^{€}=$ EU households' net accumulation of financial assets

$C A B^{\epsilon}=$ UK current account

$C A B^{€}=$ EU current account

$F I N^{£}=$ UK financial account

$F I N^{€}=$ EU current account 


\section{Parameters of the MTO Model}

$\theta^{E}=\mathrm{UK}$ Tax rate $(0.3)$

$\theta^{€}=$ EU Tax rate $(0.3)$

$v_{0}=$ First parameter of UK import prices equation $(-0.00001)$

$v_{1}=$ Second parameter of UK import prices equation (0.8)

$u_{0}=$ First parameter of UK export prices equation $(-0.00001)$

$u_{1}=$ Second parameter of UK export prices equation $(0.4)$

$\varepsilon_{0}=$ Constant of the UK export equation $(-1.8)$

$\varepsilon_{1}=$ Elasticity of UK exports with respect to EU import prices relative to prices of made in EU goods (0.7)

$\varepsilon_{2}=$ Elasticity of UK export with respect to EU output (1)

$\mu_{0}=$ Constant of UK import equation $(-1.8)$

$\mu_{1}=$ Elasticity of UK imports with respect to UK import prices relative to prices of made in Britain goods (0.7)

$\mu_{2}=$ Elasticity of UK import with respect to UK output (1)

$\alpha_{1}^{E}=$ UK propensity to consume out of income (0.75)

$\alpha_{1}^{€}=$ EU propensity to consume out of income $(0.75)$

$\alpha_{2}^{£}=$ UK propensity to consume out of wealth (0.1333)

$\alpha_{2}^{€}=$ EU propensity to consume out of wealth (0.1333)

$\varphi^{£}=$ Mark-up on unit cost in UK (0.2381)

$\varphi^{€}=$ Mark-up on unit cost in EU (0.2381)

$\lambda_{i j}=$ Portfolio equations parameters $(10=0.6 ; 11=5 ; 12=5 ; 20=0.25 ; 21=5 ; 22=5 ; 40=$ $0.6 ; 41=5 ; 42=5 ; 50=0.25 ; 51=5 ; 52=5$ )

$p r^{£}=$ UK productivity (output per worker) (1.285)

$p r^{€}=$ EU productivity (output per worker) (1.285)

$r^{E}=$ Interest rate on UK bills (0.02)

$r^{€}=$ Interest rate on EU bills (0.02)

depsh $^{E}=$ Percentage of money held as deposits in UK (0.5)

depsh $^{€}=$ Percentage of money held as deposits in UK (0.5)

winf $^{£}=$ UK Wage inflation parameter $(0.055)$

winf $f^{€}=$ UK Wage inflation parameter $(0.055)$ 


\section{Equations of the MTO Model}

$$
\begin{aligned}
& Y D^{£}=\left(Y^{€}+r_{-1}^{€} B_{€ s-1}^{€}+r_{-1}^{€} B_{€ s-1}^{€} x r^{€}+F_{\text {bank }}^{€}\right)\left(1-\theta^{£}\right) \\
& Y D_{h s}^{€}=Y D^{€}+\left(\Delta x r^{€}\right) B_{E s-1}^{€} \\
& \Delta V^{£}=Y D_{h s}^{£}-C^{£} \\
& Y D^{€}=\left(Y^{€}+r_{-1}^{€} B_{€ s-1}^{€}+r_{-1}^{€} B_{€ s-1}^{€} x r^{€}+F_{\text {bank }}^{€}\right)\left(1-\theta^{€}\right) \\
& Y D_{h s}^{€}=Y D^{€}+\left(\Delta x r^{€}\right) B_{€ s-1}^{€} \\
& \Delta V^{€}=Y D_{h s}^{€}-C^{€} \\
& v^{E}=\frac{V^{£}}{p_{d s}^{E}} \\
& v^{€}=\frac{V^{€}}{p_{d s}^{€}}
\end{aligned}
$$

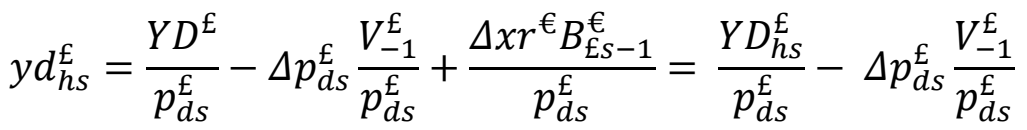

$$
\begin{aligned}
& y d_{h s}^{€}=\frac{Y D^{€}}{p_{d s}^{€}}-\Delta p_{d s}^{€} \frac{V_{-1}^{€}}{p_{d s}^{€}}+\frac{\Delta x r^{€} B_{€ s-1}^{€}}{p_{d s}^{€}}=\frac{Y D_{h s}^{€}}{p_{d s}^{€}}-\Delta p_{d s}^{€} \frac{V_{-1}^{€}}{p_{d s}^{€}} \\
& y d_{h s e}^{€}=\frac{\left(y d_{h s}^{€}+y d_{h s-1}^{£}\right)}{2} \\
& y d_{h s e}^{€}=\frac{\left(y d_{h s}^{€}+y d_{h s-1}^{€}\right)}{2} \\
& \log \left(x^{€}\right)=\varepsilon_{0}-\varepsilon_{1}\left(\log \left(p_{m-1}^{€}\right)-\log \left(p_{\text {madeEU-1 }}^{€}\right)\right)+\varepsilon_{2} \log \left(y^{€}\right) \\
& \log \left(i m^{£}\right)=\mu_{0}-\mu_{1}\left(\log \left(p_{m-1}^{ \pm}\right)-\log \left(p_{\text {madeUK-1 }}^{£}\right)\right)+\mu_{2} \log \left(y^{£}\right) \\
& x^{€}=i m^{€} \\
& i m^{€}=x^{€} \\
& X^{£}=x^{E} p_{x}^{\epsilon}
\end{aligned}
$$




$$
\begin{aligned}
& X^{€}=x^{€} p_{x}^{€} \\
& I M^{£}=i m^{£} p_{m}^{€} \\
& I M^{€}=i m^{€} p_{m}^{€} \\
& c^{£}=\alpha_{1}^{€} y d_{h s e}^{£}+\alpha_{2}^{£} v_{-1}^{£} \\
& c^{€}=\alpha_{1}^{€} y d_{h s e}^{€}+\alpha_{2}^{€} v_{-1}^{€} \\
& C^{£}=c^{£} p_{d s}^{£} \\
& C^{€}=c^{€} p_{d s}^{€} \\
& s^{£}=c^{£}+g^{£}+x^{£} \\
& s^{€}=c^{€}+g^{€}+x^{€} \\
& S^{£}=s^{£} p_{S}^{£} \\
& S^{€}=s^{€} p_{s}^{€} \\
& D S^{£}=S^{£}-X^{£} \\
& D S^{€}=S^{€}-X^{€} \\
& d s^{£}=s^{£}-x^{£} \\
& d s^{€}=s^{€}-x^{€} \\
& Y^{£}=S^{£}-I M^{£} \\
& Y^{€}=S^{€}-I M^{€} \\
& y^{£}=s^{£}+i m^{£} \\
& y^{€}=s^{€}+i m^{€} \\
& N^{£}=\frac{y^{£}}{p r^{£}} \\
& N^{€}=\frac{y^{€}}{p r^{€}}
\end{aligned}
$$




$$
\begin{aligned}
& \log \left(p_{m}^{€}\right)=v_{0}-v_{1} * \log \left(x r^{£}\right)+\left(1-v_{1}\right) \log \left(p_{\text {madeUK }}^{€}\right)+v_{1} \log \left(p_{\text {madeEU }}^{€}\right) \\
& \log \left(p_{x}^{£}\right)=u_{0}-u_{1} * \log \left(x r^{£}\right)+\left(1-u_{1}\right) \log \left(p_{\text {madeUK }}^{€}\right)+u_{1} \log \left(p_{\text {madeEU }}^{€}\right) \\
& p_{x}^{€}=p_{m}^{€} x r^{€} \\
& p_{m}^{€}=p_{x}^{€} x r^{€} \\
& p_{\text {madeUK }}^{£}=\left(1+\varphi^{£}\right) U C^{£}=\left(1+\varphi^{£}\right) \frac{W^{£} N^{£}}{y^{£}}=\left(1+\varphi^{£}\right) \frac{W^{£} N^{£}}{s^{£}-i m^{€}} \\
& p_{\text {madeEU }}^{€}=\left(1+\varphi^{€}\right) U C^{€}=\left(1+\varphi^{€}\right) \frac{W^{€} N^{€}}{y^{€}}=\left(1+\varphi^{€}\right) \frac{W^{€} N^{€}}{s^{€}-i m^{€}}
\end{aligned}
$$

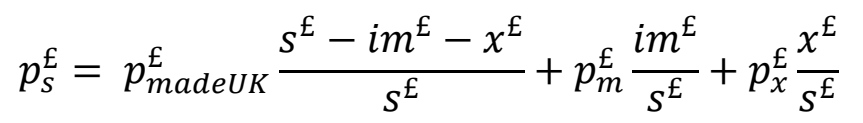

$$
\begin{aligned}
& p_{s}^{€}=p_{\text {madeUs }}^{€} \frac{s^{€}-i m^{€}-x^{€}}{s^{€}}+p_{m}^{€} \frac{i m^{€}}{s^{€}}+p_{x}^{€} \frac{x^{€}}{s^{€}} \\
& p_{d s}^{£}=\left(S^{£}-X^{£}\right) /\left(s^{£}-x^{£}\right) \\
& p_{d s}^{€}=\left(S^{€}-X^{€}\right) /\left(s^{€}-x^{€}\right) \\
& I N F^{£}=\left(p_{d s}^{£}-p_{d s-1}^{£}\right) / p_{d s-1}^{£} \\
& I N F^{€}=\left(p_{d s}^{€}-p_{d s-1}^{€}\right) / p_{d s-1}^{€} \\
& W^{£}=W_{s}^{£}\left(1+W_{i n c}^{£}\right) \\
& W^{€}=W_{s}^{€}\left(1+W_{\text {inc }}^{€}\right) \\
& F_{W}^{E}=1 \text { iff }\left(U N_{p}^{€}<w i n f^{£}\right) \\
& F_{W}^{€}=1 \text { iff }\left(U N_{p}^{€}<w i n f^{€}\right) \\
& W_{\text {incmax }}^{£}=1 \text { iff }\left(W_{\text {inc }}^{£}<0.015\right) \\
& W_{\text {incmax }}^{€}=1 \text { iff }\left(W_{\text {inc }}^{€}<0.015\right) \\
& W_{\text {inc }}^{£}=W_{\text {inc-1 }}^{£}\left(0.0002 F_{W}^{€} W_{\text {incmax }}^{£}\right)
\end{aligned}
$$




$$
\begin{aligned}
& W_{\text {inc }}^{€}=W_{\text {inc-1 }}^{€}\left(0.0002 F_{W}^{€} W_{\text {incmax }}^{€}\right) \\
& U N^{£}=\left(N_{\text {full }}^{€}-N^{£}\right) / N_{\text {full }}^{£} \\
& U N^{€}=\left(N_{\text {full }}^{€}-N^{€}\right) / N_{\text {full }}^{€} \quad(60) \\
& U N_{p}^{€}=\left(N_{\text {full }}^{€}-N^{£}+J G_{n}^{£}\right) / N_{\text {full }}^{£} \\
& U N_{p}^{€}=\left(N_{\text {full }}^{€}-N^{€}+J G_{n}^{€}\right) / N_{\text {full }}^{€} \\
& J G_{n}^{€}=\frac{g_{j g}^{£}}{p r^{£}} \\
& J G_{n}^{€}=\frac{g_{j g}^{€}}{p r^{€}} \\
& B_{€ d}^{£}=V^{£}\left(\lambda_{10}+\lambda_{11} r^{£}-\lambda_{12} r^{€}\right) \\
& B_{£ d}^{€}=V^{£}\left(\lambda_{20}+\lambda_{21} r^{£}-\lambda_{22} r^{€}\right) \\
& H_{h}^{€}=V^{£}-B_{£ s}^{€}-B_{£ s}^{€} x r^{€}-D E P_{\text {bankd }}^{€} \\
& D E P_{\text {bankd }}^{€}=\left(V^{€}-B_{€ s}^{€}-B_{E s}^{€} x r^{€}\right) d e p s h^{£} \\
& B_{€ d}^{€}=V^{€}\left(\lambda_{40}+\lambda_{41} r^{€}-\lambda_{42} r^{€}\right) \\
& B_{€ d}^{€}=V^{€}\left(\lambda_{50}-\lambda_{51} r^{€}+\lambda_{52} r^{€}\right) \\
& H_{h}^{€}=V^{€}-B_{€ s}^{€}-B_{€ s}^{€} x r^{€}-D E P_{\text {bankd }}^{€} \\
& D E P_{\text {bankd }}^{€}=\left(V^{€}-B_{€ s}^{€}-B_{€ s}^{€} x r^{£}\right) d e p s h^{€} \\
& H_{s}^{€}=H_{h}^{€}+R E S^{€} \\
& B_{£ s}^{£}=B_{£ d}^{£} \\
& H_{s}^{€}=H_{h}^{€}+R E S^{£} \\
& B_{€ s}^{€}=B_{€ d}^{€} \\
& B_{€ S}^{€}=B_{€ d}^{€} x r^{€}
\end{aligned}
$$




$$
\begin{aligned}
& B_{€ s}^{€}=B_{S}^{€}-B_{€ s}^{€}-B_{b a n k}^{€}-B_{c b € s}^{€} \\
& x r^{£}=\frac{B_{£ s}^{€}}{B_{£ d}^{€}} \\
& x r^{€}=\frac{1}{x r^{€}} \quad(80) \\
& G^{£}=g^{£} p_{d s}^{£} \\
& g^{£}=g_{b a s e}^{£}+g_{j g}^{£} \\
& G^{€}=g^{€} p_{d s}^{€} \\
& g^{€}=g_{\text {base }}^{€}+g_{j g}^{€} \\
& T^{£}=\theta^{£}\left(Y^{€}+r_{-1}^{€} B_{€ s-1}^{£}+r_{-1}^{€} B_{€ s-1}^{€} x r^{€}+F_{\text {bank }}^{€}\right) \\
& T^{€}=\theta^{€}\left(Y^{€}+r_{-1}^{€} B_{€ s-1}^{€}+r_{-1}^{€} B_{€ s-1}^{€} x r^{€}+F_{\text {bank }}^{€}\right) \\
& B_{c b £}^{£}=B_{S}^{€}-B_{€ s}^{£}-B_{€ s}^{£}-B_{b a n k}^{£} \\
& B_{c b}^{€}=H_{s}^{€} \quad(88) \\
& F_{c b}^{£}=r_{-1}^{£} B_{c b E s-1}^{£} \\
& F_{c b}^{€}=r_{-1}^{€} B_{c b € s-1}^{€} \quad \text { (90) } \\
& \Delta B_{s}^{£}=G^{£}-T^{£}+r_{-1}^{£} B_{s-1}^{£}-F_{c b}^{£} \\
& \Delta B_{S}^{€}=G^{€}-T^{€}+r_{-1}^{€} B_{s-1}^{€}-F_{c b}^{€} \\
& D E P_{\text {bank }}^{€}=D E P_{\text {bankd }}^{€} \\
& D E P_{\text {bank }}^{€}=D E P_{\text {bankd }}^{€} \\
& R E S^{£}=0.1\left(D E P_{\text {bank }}^{£}\right) \\
& R E S^{€}=0.1\left(D E P_{\text {bank }}^{€}\right) \\
& B_{\text {bank }}^{£}=D E P_{\text {bank }}^{£}-R E S^{£} \\
& B_{\text {bank }}^{€}=D E P_{\text {bank }}^{€}-R E S^{€}
\end{aligned}
$$




$$
\begin{aligned}
& F_{\text {bank }}^{€}=r_{-1}^{€} B_{\text {bank-1 }}^{€} \\
& F_{\text {bank }}^{€}=r_{-1}^{€} B_{\text {bank-1 }}^{€} \quad \text { (100) } \\
& P S B R^{£}=\Delta B_{S}^{£} \\
& P S B R^{€}=\Delta B_{S}^{€} \\
& N A F A^{£}=C A B^{£}+P S B R^{£} \quad(103) \\
& N A F A^{€}=C A B^{€}+P S B R^{€} \\
& C A B^{£}=X^{£}-I M^{£}+r_{-1}^{€} B_{€ s-1}^{€} x r^{€}-r_{-1}^{£} B_{€ s-1}^{€} \\
& C A B^{€}=X^{€}-I M^{€}+r_{-1}^{€} B_{€ s-1}^{€} x r^{€}-r_{-1}^{€} B_{€ s-1}^{€} \\
& F I N^{€}=\Delta B_{€ S}^{€}-\Delta B_{€ S}^{€} x r^{€} \\
& F I N^{€}=\Delta B_{€ S}^{€}-\Delta B_{€ S}^{€} x r^{€}
\end{aligned}
$$

Redundant equation:

$$
B_{c b €}^{€}=B_{s}^{€}-B_{€ s}^{€}-B_{€ s}^{€}-B_{b a n k}^{€}
$$

